\title{
Growth and survival of spat, juveniles and adult Akoya pearl oyster Pinctada imbricata fucata (Gould, 1850) in different rearing conditions and stocking densities
}

\author{
R. MARY RINJU, M. K. ANIL AND E. SHERLY WILLIAMS* \\ Research Centre of ICAR-Central Marine Fisheries Research Institute, Vizhinjam - 695 521, Kerala, India. \\ ${ }^{1}$ Fatima Mata National College, Kollam - 691 001, Kerala, India \\ e-mail: rinjushiju@yahoo.com
}

\begin{abstract}
Growth trials were conducted using hatchery produced spat of Pinctada imbricata fucata (Gould, 1850) having average dorso-ventral measurement (DVM) of $3.99 \mathrm{~mm}$, hinge length (HL) $3.94 \mathrm{~mm}$, thickness (THK) $1.25 \mathrm{~mm}$ and weight (WGT) $0.008 \mathrm{~g}$. The first experiment was a comparative growth assessment of spat grown in one ton FRP tanks in the hatchery and with that of spat reared in micron meshed cages under open sea conditions for a period of three months. During the third month, spats grown in micron meshed cages showed growth increments of $7.83 \mathrm{~mm}$ (DVM), $4.86 \mathrm{~mm}$ (HL), 1.61 $\mathrm{mm}$ (THK) and $0.192 \mathrm{~g}$ (WGT) whereas those grown in FRP tanks grew only by $0.95 \mathrm{~mm}$ (DVM), $0.5 \mathrm{~mm}$ (HL), $0.46 \mathrm{~mm}$ (THK) and $0.004 \mathrm{~g}$ (WGT) indicating faster growth in open sea conditions. Second experiment was conducted to elucidate the effect of stocking density on the growth and survival of juveniles reared in plastic baskets at different stocking densities viz., $200\left(0.03\right.$ nos. $\left.\mathrm{cm}^{-3}\right), 300\left(0.049\right.$ nos. $\left.\mathrm{cm}^{-3}\right), 400\left(0.065\right.$ nos. $\left.\mathrm{cm}^{-3}\right), 500\left(0.08\right.$ nos. $\left.\mathrm{cm}^{-3}\right), 600\left(0.098\right.$ nos. $\left.\mathrm{cm}^{-3}\right), 700$ $\left(0.11\right.$ nos. $\left.\mathrm{cm}^{-3}\right), 800\left(0.13\right.$ nos. $\left.\mathrm{cm}^{-3}\right), 900\left(0.14\right.$ nos. $\left.\mathrm{cm}^{-3}\right)$ and $1000\left(0.16\right.$ nos. $\left.\mathrm{cm}^{-3}\right)$ numbers per basket. Results indicated that $P$. imbricata fucata juveniles can be grown at stocking densities of upto 400 nos per basket for a period of five months with $90 \%$ survival without much reduction in growth. Third experiment was conducted on the growth of $P$. imbricata fucata subadults in box cages at different stocking densities viz., $200\left(0.006\right.$ nos. $\left.\mathrm{cm}^{-3}\right), 300\left(0.01 \mathrm{nos} . \mathrm{cm}^{-3}\right), 400\left(0.013\right.$ nos. $\left.\mathrm{cm}^{-3}\right)$, $500\left(0.016\right.$ nos. $\left.\mathrm{cm}^{-3}\right), 600\left(0.02\right.$ nos. $\left.\mathrm{cm}^{-3}\right), 700\left(0.023\right.$ nos. $\left.\mathrm{cm}^{-3}\right), 800\left(0.026\right.$ nos. $\left.\mathrm{cm}^{-3}\right), 900\left(0.03\right.$ nos. $\left.\mathrm{cm}^{-3}\right)$ and 1000 $\left(\right.$ nos. $\left.\mathrm{cm}^{-3}\right)$ numbers per cage. Survival rates ranged from 98.5 to $98.6 \%$ at stocking densities up to 400 nos. per cage during the fifth month without any significant variation in the DVM, HL and THK of oysters.
\end{abstract}

Keywords: Box cages, Growth, Physicochemical parameters, Pinctada imbricata fucata, Plastic baskets

\section{Introduction}

Mass production of seed and fully grown oysters are essential for successful commercial pearl culture. Along with environmental suitability and feed availability, spatial requirement is a critical factor that affects the growth and survival of pearl oyster and therefore the economics of operation. Pinctada imbricata fucata (Gould, 1850) is one of the major bivalve mollusc species, in the family Pteriidae which produces Akoya pearls of high economic value. According to Liu et al. (2012), approximately a quarter of the pearl production (about US\$160 million) is from the species P. imbricata fucata. Rao and Rao (1974) also opined that P. imbricata fucata is the most important pearl producing mollusc from the Indian coasts as the pearl yield from the other five species viz., P. margaritifera, $P$. chemnitzii, P. sugillata, P. maxima and P. albina are low and are not of high quality.

Due to its importance in pearl production, optimisation of rearing technology for $P$. fucata is essential for maximising commercial gain from farming operations. Availability of feed, stocking density, depth of rearing, environmental conditions and mineral composition of seawater greatly influences the growth and pearl production. Investigations carried out by Sims (1994), Taylor et al. (1997), Jagadis et al. (2006), Rao (2007) and Aji (2011) also pointed out the importance of stocking density in the economics of pearl culture farms. Matthew and Southgate (2016) studied the effects of stocking density and ration on the survival and growth of winged pearl oyster (Pteria penguin) larvae which were fed by commercially available micro-algal concentrates and provided information for optimising the hatchery culture protocols for the production of $P$. penguin. Monteforte et al. (2005) studied the effect of stocking density on the growth and survival of the rainbow pearl oyster Pteria sterna (Gould 1852) during nursery and late culture phase and opined that each stocking density has its own profile. The gradual reduction in the density which is performed during the production cycle is more related to growth and absolute abundance than with the onset of intrinsic events 
of mortality involving the intra-competition and selfthinning (Frechette et al., 1996, Monteforte et al., 2005).

As there are very few studies on the effect of stocking rates on growth of $P$. imbricata fucata during different life stages, the present study was undertaken to assess the effect of stocking density on the growth and survival of spat, juveniles and adults of $P$. imbricata fucata.

\section{Materials and methods}

P. imbricata fucata larvae were produced by strip spawning following the method described by Anil et al. (2014) and the larvae obtained were reared in the hatchery of Vizhinjam Research Centre of ICAR-Central Marine Fisheries Research Institute (ICAR-CMFRI) for 103 days until they attained an average dorso-ventral measurement (DVM) of $3.99 \mathrm{~mm}$, hinge length (HL) of $3.94 \mathrm{~mm}$, thickness (THK) of $1.25 \mathrm{~mm}$ and weight (WGT) of $0.008 \mathrm{~g}$. In the hatchery, one ton capacity FRP tanks were used for rearing $P$. imbricata fucata larvae with water exchange on alternate days providing micro algal mixed diet of Isochrysis galbana, Pavlova lutherii and Dicretaria sp. during the larval phase and diatom species viz., Chaetoceros calcitrans and Thalassiosira sp. were added prior to settlement phase. The feeding schedule followed was; D - Veliger larvae (day 1 - 8) : 3000 - 5000 cells larvae $^{-1}$ day $^{-1}$; Umbo stage (day 9 - 15): 10,000 cells larvae ${ }^{-1}$ day $^{-1}$; Eyespot stage (day 16 - 17): 15,000 cells larvae ${ }^{-1}$ day $^{-1}$, Pediveligers and plantigrades (day 20 - 23): 25,000 cells larvae $^{-1}$ day $^{-1}$ and spats (day 24 - 29) : 30,000 cells larvae ${ }^{-1}$ day $^{-1}$; day 30 - 60: 50,000 cells larvae ${ }^{-1}$ day $^{-1}$ and for day 60 - 90: $>1,00000$ cells larvae ${ }^{-1}$ day $^{-1}$ ). These spats were used for growth and survival studies for a period of two years (March 2015 to February 2017).

After 103 days, approximately 25000 spats each were transferred from the FRP tanks to micron meshed cages at a stocking density of 3.42 nos. $\mathrm{cm}^{-3}$ (Fig. 1) with three replicates for nursery rearing in open sea conditions. Simultaneously, equal numbers of spats were reared $\left(0.03\right.$ nos. $\left.\mathrm{cm}^{-3}\right)$ in one ton FRP tanks in the hatchery with three replicates. Feeding rate was 2,00000 - 3,00000 cells larvae $^{-1}$ day $^{-1}$. Micron meshed cages with a mesh size of $1 \times 1 \mathrm{~mm}$ of $93 \mathrm{~cm}$ length with corresponding diameter of $10 \mathrm{~cm}$ were used for these nursery rearing trials. Comparative study was done on the growth and survival of the oyster spats in micron meshed cages and FRP tanks by recording, monthly morphometric data which included DVM (mm), HL (mm), THK (mm) and WGT $(\mathrm{g})$ for a period of three months.

In the second trial, growth of spat was studied in plastic baskets (Fig. 2) at different stocking densities. The plastic baskets used for rearing had a diameter of $24 \mathrm{~cm}$,

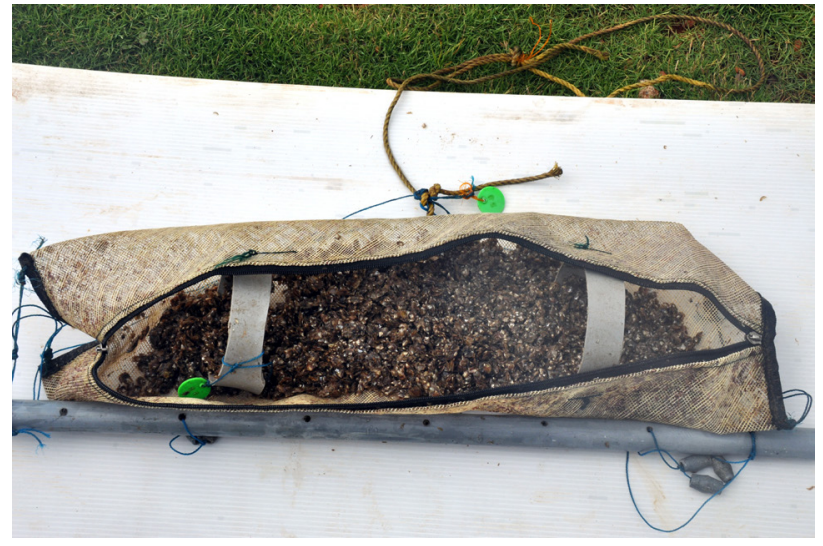

Fig. 1. Micron meshed cages used for nursery rearing of P. imbricata fucata spat

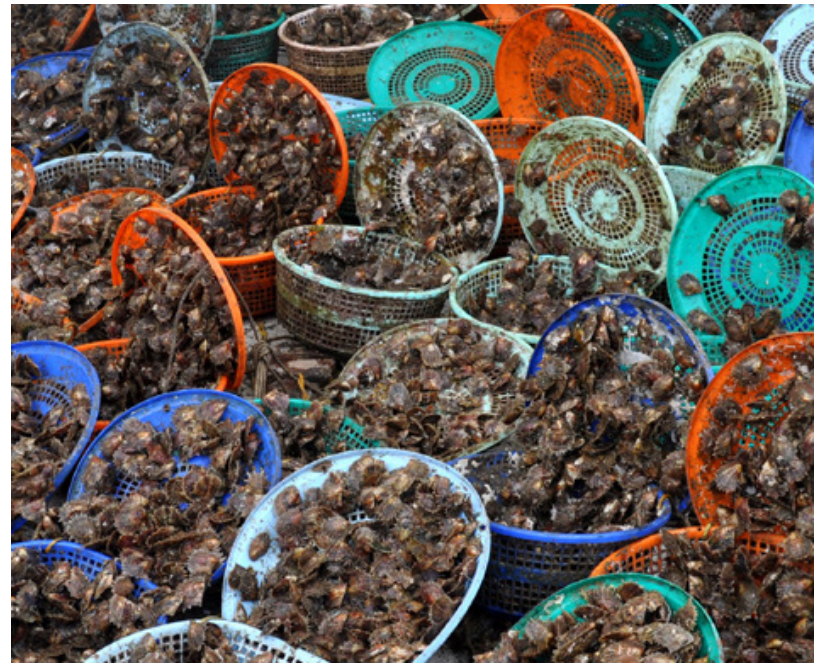

Fig. 2. Plastic baskets used for nursery rearing of $P$. imbricata fucata juveniles

height $13.5 \mathrm{~cm}$ and a total volume of $6104.16 \mathrm{~cm}^{3}$. The total available opening of a plastic basket was $700 \mathrm{~cm}^{2}$ with rows of rectangular openings of size $1 \mathrm{~cm} \times 1 \mathrm{~cm}$ on the body and $1 \mathrm{~cm} \times 0.5 \mathrm{~cm}$ openings on the lid. During the first month, the baskets were covered with mosquito netting of mesh size $1 \mathrm{~mm}$ in order to prevent loss of small spats through the basket openings. Spat having an average DVM of $11.78 \mathrm{~mm}$, HL $8.5 \mathrm{~mm}$, THK $2.81 \mathrm{~mm}$ and WGT of $0.136 \mathrm{~g}$ were stocked at different stocking densities of $200\left(0.03\right.$ nos. $\left.\mathrm{cm}^{-3}\right), 300\left(0.049\right.$ nos. $\left.\mathrm{cm}^{-3}\right), 400(0.065$ nos. $\left.\mathrm{cm}^{-3}\right), 500\left(0.08\right.$ nos. $\left.\mathrm{cm}^{-3}\right), 600\left(0.098\right.$ nos. $\left.\mathrm{cm}^{-3}\right)$, $700\left(0.11\right.$ nos. $\left.\mathrm{cm}^{-3}\right), 800\left(0.13\right.$ nos. $\left.\mathrm{cm}^{-3}\right), 900$ (0.14 nos. $\left.\mathrm{cm}^{-3}\right)$ and $1000\left(0.16\right.$ nos. $\left.\mathrm{cm}^{-3}\right)$ numbers in each basket. Triplicates were maintained for each stocking density and growth and survival was studied for a period of five months. Monthly morphometric data including DVM (mm), HL (mm), THK (mm) and WGT (g) were recorded. 
After five months, all the juveniles from plastic baskets were transferred to box cages (Fig. 3) to prevent stunted growth. The juveniles possessed average DVM of $36.56 \mathrm{~mm}$, HL of $29.98 \mathrm{~mm}$, THK $12.73 \mathrm{~mm}$ and WGT of $6.62 \mathrm{~g}$ at the time of transfer to box cages. The box cages used had dimensions of $50 \mathrm{~cm} \mathrm{X} 50 \mathrm{~cm} \mathrm{X} 12 \mathrm{~cm}$ with a mesh size of $25 \mathrm{~mm}$. Stocking densities of $200(0.006$ nos. $\left.\mathrm{cm}^{-3}\right), 300\left(0.01\right.$ nos. $\left.\mathrm{cm}^{-3}\right), 400\left(0.013\right.$ nos. $\left.\mathrm{cm}^{-3}\right), 500$ $\left(0.016\right.$ nos. $\left.\mathrm{cm}^{-3}\right), 600\left(0.02\right.$ nos. $\left.\mathrm{cm}^{-3}\right), 700$ (0.023 nos. $\left.\mathrm{cm}^{-3}\right), 800\left(0.026\right.$ nos. $\left.\mathrm{cm}^{-3}\right), 900\left(0.03\right.$ nos. $\left.\mathrm{cm}^{-3}\right)$ and 1000 $\left(\right.$ nos. $\left.\mathrm{cm}^{-3}\right)$ numbers per cage were tested and triplicates were maintained for each stocking density. Study was continued for a period of five months and monthly data DVM (mm), HL (mm), THK (mm) and WGT $(\mathrm{g})$ were recorded. On the fifth month, no significant difference was noted in the growth rates of oysters and stocking density was further reduced to 100 nos. per cage.

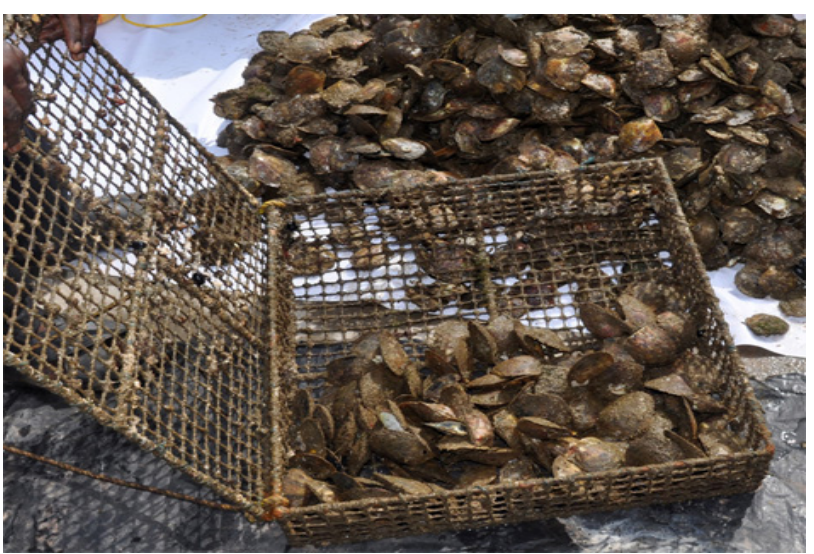

Fig. 3. Box cage used for rearing of sub-adults of $P$. imbricata fucata

Shell dimensions were measured using digital vernier calipers (to the nearest $0.1 \mathrm{~mm}$ ) and an electronic balance (Sartorius, $d=0.1 \mathrm{mg}$ ) was used for recording the weight. Growth study results were statistically analysed by one way ANOVA and t-tests using SPSS software.

The micron meshed cages, plastic baskets and box cages were hung from the raft system moored at an average depth of $5-6 \mathrm{~m}$ in the Vizhinjam Bay situated along the southern Kerala Coast ( $76^{\circ} 59^{\prime} \mathrm{E}$; 8 ${ }^{\circ} 22^{\prime} 30^{\prime \prime} \mathrm{N}$ ). The depth of the bay varies from 4 to $15 \mathrm{~m}$ and the bottom of the bay is sandy.

Fortnightly data was recorded on the physicochemical parameters of water in the experimental site in the Vizhinjam Bay which comprised atmospheric and water temperature $\left({ }^{\circ} \mathrm{C}\right)$, salinity $(\mathrm{ppt}), \mathrm{pH}$, turbidity, ammonia, nitrite, nitrate, phosphate, silicate, dissolved oxygen, primary productivity and chlorophyll $a$, analysed following standard methods. Temperature was measured using a thermometer, salinity by means of handheld master refractometer (ATAGO), $\mathrm{pH}$ using compact $\mathrm{pH}$ meter (LAQUA twin) and turbidity using nephelometer. Ammonia-N, nitrite-N, nitrate-N, phosphate and silicate were analysed using test kits (MERCK) by adopting photometric method (NOVA 60, Spectroquant). Dissolved oxygen was analysed following the method of Winkler (1888). Primary productivity was recorded using light and dark bottle method (Strickland and Parsons, 1972) and Chlorophyll $a$ concentration was analysed with UV Visible Spectrophotometer (Evolution 201) (Strickland and Parsons, 1972).

During nursery rearing in micron meshed cages and during the first month of rearing in plastic baskets which were covered with velon meshes, weekly agitation along with scrubbing and rinsing of cages and baskets in seawater was done to remove the accumulated detritus and mud. In the case of sub-adult rearing in box cages, weekly agitation was done to avoid the accumulation of mud and detritus to facilitate free flow of water during rearing. Fortnightly cleaning of oysters was done to remove foulers and borers, depending on the level of fouling. The entry of pests like small crabs and gastropods was prevented by fortnightly checking and removal of predators.

\section{Results}

Comparison of P. imbricata fucata spat growth in FRP tanks and micron meshed cages

During the first month, P. imbricata fucata spats reared in FRP tanks $\left(0.03\right.$ nos. $\left.\mathrm{cm}^{-3}\right)$ showed increments of $0.01 \mathrm{~mm}$ (DVM), $0.01 \mathrm{~mm}$ (HL), $0.02 \mathrm{~mm}$ (THK) and $0.0007 \mathrm{~g}$ (WGT) whereas, growth of spats stocked in micron meshed cages $\left(3.42\right.$ nos. $\left.\mathrm{cm}^{-3}\right)$ increased by 0.3 $\mathrm{mm}$ (DVM), $0.17 \mathrm{~mm}$ (HL), $0.74 \mathrm{~mm}$ (THK) and $0.002 \mathrm{~g}$ (WGT) (Table 1). The study was continued for a period of three months and during the third month, spats reared in FRP tanks showed net increase in growth by $0.95 \mathrm{~mm}$ (DVM), $0.5 \mathrm{~mm}$ (HL), $0.46 \mathrm{~mm}$ (THK) and $0.004 \mathrm{~g}$ (WGT) while those reared in micron meshed cages grew by $7.83 \mathrm{~mm}$ (DVM), $4.86 \mathrm{~mm}$ (HL), $1.61 \mathrm{~mm}$ (THK) and $0.192 \mathrm{~g}$ (WGT). Rate of increase in DVM shown by spats grown in FRP tanks and micron meshed cages during the three months period are graphically represented in (Fig. 4). Survival percentage was higher in micron meshed cages (99.4\%) than those reared in FRP tanks (96.9\%) (Table 2). Growth of $P$. imbricata fucata spat grown in micron meshed cages were found to be significantly higher $(p<0.001)$ compared to that of FRP tanks. 
Table 1. Growth rates of P. imbricata fucata spat grown in FRP tanks and micron meshed cages during the experimental period

\begin{tabular}{llllll}
\hline \multirow{2}{*}{ Month/Interval } & \multicolumn{2}{c}{ Micron meshed cage } & & \multicolumn{2}{c}{ FRP tank } \\
\cline { 2 - 3 } \cline { 5 - 5 } & Survival (Nos.) & Survival (\%) & & Survival (Nos.) & Survival (\%) \\
\hline Initial & 25000 & 100 & 25000 & 100 \\
After one month & 24980 & 99.92 & & 24246 & 96.984 \\
After two months & 24888 & 99.552 & 24183 & 96.732 \\
After three months & 24850 & 99.4 & 24000 & 96 \\
\hline
\end{tabular}

Table 2. Survival rate of P. imbricata fucata spat grown in micron meshed cages and FRP tanks

\begin{tabular}{llllll}
\hline Rearing system & Parameters & Initial & First month & Second month & Third month \\
\hline FRP tanks & DVM (mm) & 3.99 & 0.01 & 0.26 & 0.68 \\
& HL (mm) & 3.94 & 0.01 & 0.14 & 0.35 \\
& THK (mm) & 1.25 & 0.02 & 0.04 & 0.36 \\
& WGT (g) & 0.008 & 0.0007 & 0.0013 & 0.002 \\
\hline Micron meshed cages & DVM (mm) & 3.99 & 0.3 & 3.45 & 4.08 \\
& HL (mm) & 3.94 & 0.17 & 0.76 & 2.93 \\
& THK (mm) & 1.25 & 0.74 & 0.016 & 0.83 \\
& WGT (g) & 0.008 & 0.002 & 0.174 \\
\hline
\end{tabular}

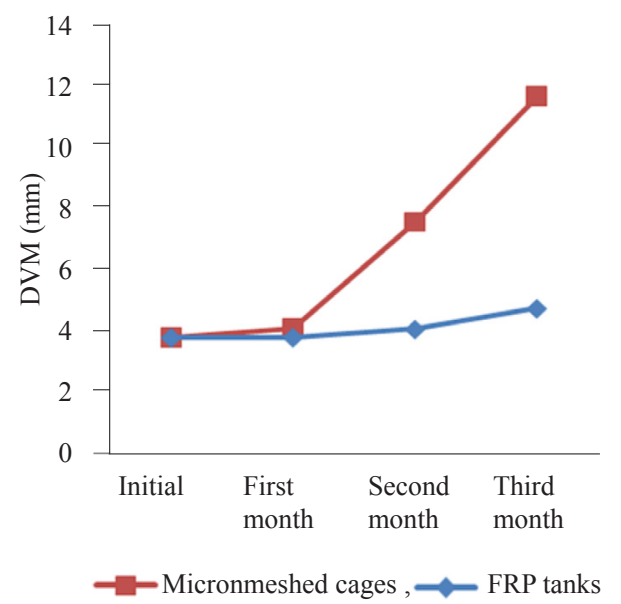

Fig. 4. Average growth of P. imbricata fucata spat in micron meshed cages and FRP tanks

Growth and survival of P. fucata juveniles grown in plastic baskets at various stocking densities

Juveniles showed growth increments of $10.2 \mathrm{~mm}$ (DVM), $8.8 \mathrm{~mm}$ (HL), $3.91 \mathrm{~mm}$ (THK), $1.38 \mathrm{~g}$ (WGT) at stocking density of 200 whereas it was, $7.99 \mathrm{~mm}$ (DVM), $8.12 \mathrm{~mm}$ (HL), $3.71 \mathrm{~mm}$ (THK), $0.814 \mathrm{~g}$ (WGT) at stocking density of 500 nos. per basket and $5.27 \mathrm{~mm}$ (DVM), $3.83 \mathrm{~mm}$ (HL), $1.11 \mathrm{~mm}$ (THK), $0.54 \mathrm{~g}$ (WGT) in stocking density of 1000 nos. per basket in the first month (Table 3). During the fifth month, juveniles stocked in stocking density of 200 nos. per basket showed net increments in growth by $32.59 \mathrm{~mm}$ (DVM), $29.71 \mathrm{~mm}$ (HL), $13.64 \mathrm{~mm}$ (THK) and $10.48 \mathrm{~g}$ (WGT) whereas those grown in stocking density of
400 nos. per basket showed increments of $27.12 \mathrm{~mm}$ (DVM), $22.82 \mathrm{~mm}$ (HL), $12.27 \mathrm{~mm}$ (THK) and $7.094 \mathrm{~g}$ (WGT) and the growth of those stocked at density of 500 nos. per basket showed increments of $23.13 \mathrm{~mm}$ (DVM), $20.77 \mathrm{~mm}$ (HL), $10.25 \mathrm{~mm}$ (THK) and $3.914 \mathrm{~g}$ (WGT). Severe mortality was observed at stocking densities of 800,900 and 1000 nos. per basket during the third month with percentage survival of 72.6, 62 and 52\% (Table 4). Growth of juveniles (DVM) at different stocking densities during the five month period is graphically represented in Fig. 5. Growth of $P$. imbricata fucata spat in plastic baskets at different stocking densities of 200, 300, 400, 500 and 600 nos. per basket were found to be significantly different $(\mathrm{p}<0.001)$ during the fifth month.

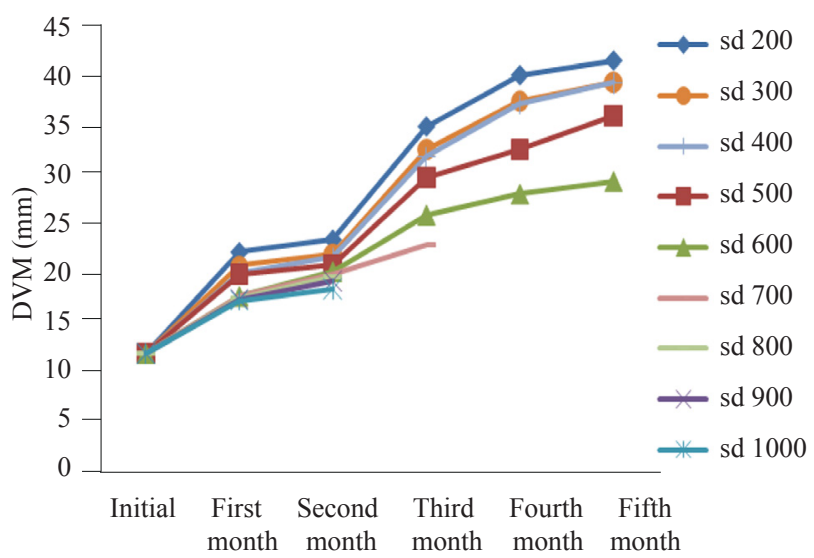

Fig. 5. Average growth of $P$. imbricata fucata juveniles in plastic baskets at different stocking densities 
Table 3. Growth rates of $P$. imbricata fucata spat grown in plastic baskets at different stocking densities

\begin{tabular}{|c|c|c|c|c|c|c|c|}
\hline Stocking density & Parameters & Initial & First month & Second month & Third month & Fourth month & Fifth month \\
\hline \multirow[t]{4}{*}{200} & DVM (mm) & 11.78 & 10.2 & 2.48 & 11.36 & 5.15 & 3.4 \\
\hline & $\mathrm{HL}(\mathrm{mm})$ & 8.5 & 8.83 & 2.44 & 10.4 & 3.95 & 4.09 \\
\hline & THK (mm) & 2.81 & 3.91 & 1.97 & 4.78 & 0.97 & 2.01 \\
\hline & WGT $(\mathrm{g})$ & 0.136 & 1.38 & 0.28 & 3.21 & 3.09 & 2.52 \\
\hline \multirow[t]{4}{*}{300} & DVM (mm) & 11.78 & 8.83 & 2.43 & 10.52 & 5.31 & 3.36 \\
\hline & HL (mm) & 8.5 & 8.37 & 2.2 & 9.57 & 1.7 & 3.77 \\
\hline & THK (mm) & 2.81 & 3.82 & 1.59 & 4.76 & 0.82 & 1.36 \\
\hline & WGT (g) & 0.136 & 1.067 & 0.17 & 2.49 & 2.36 & 2.5 \\
\hline \multirow[t]{4}{*}{$\overline{400}$} & DVM (mm) & 11.78 & 8.13 & 1.93 & 10.06 & 4.81 & 2.19 \\
\hline & $\mathrm{HL}(\mathrm{mm})$ & 8.5 & 8.12 & 2.04 & 7.27 & 1.64 & 3.75 \\
\hline & THK (mm) & 2.81 & 3.75 & 1.5 & 4.28 & 0.75 & 1.99 \\
\hline & WGT (g) & 0.136 & 0.944 & 0.12 & 2.29 & 1.69 & 2.05 \\
\hline \multirow[t]{4}{*}{500} & DVM (mm) & 11.78 & 7.99 & 1.8 & 8.67 & 2.83 & 1.84 \\
\hline & $\mathrm{HL}(\mathrm{mm})$ & 8.5 & 8.08 & 1.96 & 6.93 & 1.14 & 2.66 \\
\hline & THK (mm) & 2.81 & 3.67 & 1.31 & 2.88 & 0.61 & 1.78 \\
\hline & WGT (g) & 0.136 & 0.814 & 0.09 & 1.66 & 0.42 & 0.93 \\
\hline \multirow[t]{4}{*}{600} & DVM (mm) & 11.78 & 5.72 & 1.53 & 7.72 & 2.09 & 1.46 \\
\hline & $\mathrm{HL}(\mathrm{mm})$ & 8.5 & 5.13 & 0.93 & 6.16 & 0.91 & 1.75 \\
\hline & THK (mm) & 2.81 & 1.89 & 0.68 & 2.8 & 0.19 & 0.73 \\
\hline & WGT(g) & 0.136 & 0.814 & 0.07 & 1.64 & 0.42 & 0.29 \\
\hline \multirow[t]{4}{*}{700} & DVM (mm) & 11.78 & 5.72 & 1.24 & 2.96 & - & - \\
\hline & $\mathrm{HL}(\mathrm{mm})$ & 8.5 & 4.8 & 0.64 & 1.85 & - & - \\
\hline & THK (mm) & 2.81 & 1.58 & 0.18 & 0.26 & - & - \\
\hline & WGT(g) & 0.136 & 0.724 & 0.07 & 0.98 & - & - \\
\hline \multirow[t]{4}{*}{800} & DVM (mm) & 11.78 & 5.47 & 1.16 & - & - & - \\
\hline & $\mathrm{HL}(\mathrm{mm})$ & 8.5 & 4.43 & 0.55 & - & - & - \\
\hline & THK (mm) & 2.81 & 1.35 & 0.02 & - & - & - \\
\hline & WGT (g) & 0.136 & 0.684 & 0.06 & - & - & - \\
\hline \multirow[t]{4}{*}{900} & DVM (mm) & 11.78 & 5.42 & 1.13 & - & - & - \\
\hline & $\mathrm{HL}(\mathrm{mm})$ & 8.5 & 4.26 & 0.29 & - & - & - \\
\hline & THK (mm) & 2.81 & 1.24 & 0.01 & - & - & - \\
\hline & WGT (g) & 0.136 & 0.624 & 0.05 & - & - & - \\
\hline \multirow[t]{4}{*}{1000} & DVM (mm) & 11.78 & 5.29 & 0.91 & - & - & - \\
\hline & $\mathrm{HL}(\mathrm{mm})$ & 8.5 & 3.9 & 0.04 & - & - & - \\
\hline & THK (mm) & 2.81 & 1.12 & 0.01 & - & - & - \\
\hline & WGT (g) & 0.136 & 0.594 & 0.04 & - & - & - \\
\hline
\end{tabular}

Table 4. Survival rates of $P$. imbricata fucata spats reared in plastic baskets

\begin{tabular}{lll}
\hline Stocking density & Survival (Nos.) & Survival (\%) \\
\hline 200 (Fifth month) & 195 & 97.5 \\
300 (Fifth month) & 291 & 97 \\
400 (Fifth month) & 391 & 97.75 \\
500 (Fifth month) & 496 & 99.2 \\
600 (Fifth month) & 588 & 98 \\
700 (Fourth month) & 525 & 75 \\
800 (Third month) & 518 & 72.6 \\
900 (Third month) & 558 & 62 \\
1000 (Third month) & 590 & 52 \\
\hline
\end{tabular}

Growth and survival of $P$. imbricata fucata subadults grown in box cages at various stocking densities

Growth of subadults stocked at 200 nos. (0.006 nos. $\mathrm{cm}^{-3}$ ) showed net increments in growth by $23.51 \mathrm{~mm}$ (DVM), 20.81 mm(HL), 12.29 mm(THK) and 20.7g(WGT) whereas those stocked at 500 nos. percage $\left(0.016\right.$ nos. $\left.\mathrm{cm}^{-3}\right)$ grew by $13.98 \mathrm{~mm}$ (DVM), $8.02 \mathrm{~mm}$ (HL), $4.33 \mathrm{~mm}$ (THK) and $9.39 \mathrm{~g}$ (WGT) during the fifth month (Table 5). Fig. 6 depicts the growth of subadults (DVM) in box cages at different stocking densities during the 5 months period. Oysters grown at stocking density of 600 nos. per cage showed net growth increments by $8.98 \mathrm{~mm}$ (DVM), 
Table 5. Growth rates of $P$. imbricata fucata juveniles grown in box cages at different stocking densities

\begin{tabular}{|c|c|c|c|c|c|c|c|}
\hline Stocking densities & Parameters & Initial & First month & Second month & Third month & Fourth month & Fifth month \\
\hline \multirow{4}{*}{200} & DVM (mm) & 36.56 & 7.86 & 3.25 & 4.64 & 2.22 & 5.54 \\
\hline & $\mathrm{HL}(\mathrm{mm})$ & 29.98 & 7.83 & 2.61 & 4.3 & 1.94 & 4.13 \\
\hline & THK (mm) & 12.73 & 2.77 & 1.22 & 2.48 & 1.72 & 4.1 \\
\hline & WGT (g) & 6.62 & 5.6 & 2.96 & 2.71 & 2.95 & 6.48 \\
\hline \multirow{4}{*}{300} & DVM (mm) & 36.56 & 6.51 & 2.34 & 3.63 & 1.74 & 5 \\
\hline & $\mathrm{HL}(\mathrm{mm})$ & 29.98 & 3.54 & 2.55 & 4.29 & 0.96 & 1.67 \\
\hline & THK (mm) & 12.73 & 2.27 & 1.15 & 1.85 & 1.14 & 3.45 \\
\hline & WGT (g) & 6.62 & 3.18 & 2.76 & 2.57 & 2.18 & 3.59 \\
\hline \multirow{4}{*}{400} & DVM (mm) & 36.56 & 4.31 & 2.29 & 3.23 & 1.16 & 4.38 \\
\hline & $\mathrm{HL}(\mathrm{mm})$ & 29.98 & 1.34 & 2.19 & 3.61 & 0.56 & 0.97 \\
\hline & THK (mm) & 12.73 & 1.89 & 1.13 & 1.48 & 0.91 & 0.76 \\
\hline & WGT (g) & 6.62 & 2.88 & 2.7 & 2.38 & 1.2 & 3.42 \\
\hline \multirow{4}{*}{500} & DVM (mm) & 36.56 & 3.17 & 2.28 & 3.1 & 1.08 & 4.35 \\
\hline & $\mathrm{HL}(\mathrm{mm})$ & 29.98 & 1.23 & 2.15 & 3.59 & 0.52 & 0.53 \\
\hline & THK (mm) & 12.73 & 1.69 & 1.1 & 0.93 & 0.48 & 0.13 \\
\hline & WGT (g) & 6.62 & 2.87 & 2.58 & 1.8 & 0.94 & 1.2 \\
\hline \multirow{4}{*}{600} & DVM (mm) & 36.56 & 3.15 & 2.27 & 2.73 & 0.83 & - \\
\hline & $\mathrm{HL}(\mathrm{mm})$ & 29.98 & 1.15 & 2.05 & 3.38 & 0.3 & - \\
\hline & THK (mm) & 12.73 & 1.67 & 1.09 & 0.79 & 0.23 & - \\
\hline & WGT (g) & 6.62 & 2.77 & 2.08 & 1.75 & 0.56 & - \\
\hline \multirow{4}{*}{700} & DVM (mm) & 36.56 & 3.03 & 2.17 & 2.62 & 0.2 & - \\
\hline & $\mathrm{HL}(\mathrm{mm})$ & 29.98 & 1.01 & 1.76 & 3.03 & 0.07 & - \\
\hline & THK (mm) & 12.73 & 1.6 & 0.95 & 0.63 & 0.21 & - \\
\hline & WGT (g) & 6.62 & 2.71 & 1.91 & 1.71 & 0.33 & - \\
\hline \multirow{4}{*}{800} & DVM (mm) & 36.56 & 2.63 & 2.1 & 2.15 & - & - \\
\hline & $\mathrm{HL}(\mathrm{mm})$ & 29.98 & 0.84 & 1.54 & 2.69 & - & - \\
\hline & THK (mm) & 12.73 & 1.56 & 0.94 & 0.54 & - & - \\
\hline & WGT (g) & 6.62 & 2.67 & 1.4 & 1.67 & - & - \\
\hline \multirow{4}{*}{ SD 900} & DVM (mm) & 36.56 & 2.61 & 1.96 & 1.69 & - & - \\
\hline & $\mathrm{HL}(\mathrm{mm})$ & 29.98 & 0.56 & 1.44 & 2 & - & - \\
\hline & THK (mm) & 12.73 & 1.04 & 0.8 & 0.54 & - & - \\
\hline & WGT (g) & 6.62 & 1.7 & 1.26 & 1.55 & - & - \\
\hline \multirow{4}{*}{1000} & DVM (mm) & 36.56 & 2.03 & 1.09 & 1.45 & - & - \\
\hline & $\mathrm{HL}(\mathrm{mm})$ & 29.98 & 0.03 & 0.15 & 1.89 & - & - \\
\hline & THK (mm) & 12.73 & 0.98 & 0.48 & 0.03 & - & - \\
\hline & WGT (g) & 6.62 & 1.6 & 0.46 & 1.1 & - & - \\
\hline
\end{tabular}

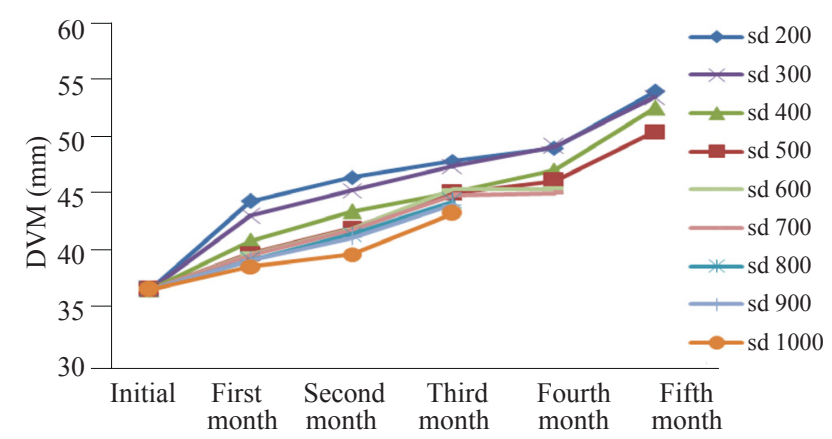

Fig. 6. Average growth of $P$. imbricata fucata subadults in box cages at different stocking densities
Table 6. Survival rate of $P$. imbricata fucata spats reared in box cages

\begin{tabular}{lll}
\hline Stocking density & Rate of survival (nos.) & Survival (\%) \\
\hline 200 (Fifth month) & 197 & 98.5 \\
300 (Fifth month) & 296 & 98.6 \\
400 (Fifth month) & 296 & 98.6 \\
500 (Fifth month) & 493 & 98.6 \\
600 (Fourth month) & 530 & 88.3 \\
700 (Fourth month) & 542 & 77.4 \\
800 (Third month) & 535 & 66.8 \\
900 (Third month) & 548 & 60.8 \\
1000 (Third month) & 609 & 60.9 \\
\hline
\end{tabular}


$6.88 \mathrm{~mm}$ (HL), $3.78 \mathrm{~mm}$ (THK), $7.16 \mathrm{~g}$ (WGT) and those stocked at 700 nos. per cage increased by $8.02 \mathrm{~mm}$ (DVM), $5.87 \mathrm{~mm}$ (HL), $3.39 \mathrm{~mm}$ (THK), $6.66 \mathrm{~g}$ (WGT) during the fourth month and mortality of oysters (stocking density of 600 : nos. per cage $88.3 \%$ survival, stocking density of 700: nos. per cage $77.4 \%$ ) were observed during the fifth month. Those grown at stocking densities of 800,900 and 1000 nos. per cage had survival rates of 99.6, 99.4 and $99.5 \%$ till three months and thereafter severe mortality was observed (Table 6). Growth of oysters in box cages at stocking densities of 200, 300, 400 and 500 nos. per cage was found to be statistically significant during the fifth month $(\mathrm{p}<0.001)$.

The spat stocked in some plastic baskets were found infested with pests like ascidians and sponges which grew profusely over the spat that adversely affected the free opening of valves of baby oysters and clogged the sides of the baskets, blocking free flow of water through the openings of the basket and resulted in retarded growth of oysters. Other foulers and borers like barnacles and polychaetes also were noticed during the present study. To prevent this, fortnightly cleaning of oyster was done depending on the level of fouling. The entry of pests like small crabs and gastropods also resulted in mortality of spats and juveniles which was prevented by fortnightly checking and removal of predators.

The range of physico-chemical parameters recorded in the water in the experimental site during the study period were, atmospheric temperature: $25.4-32.6^{\circ} \mathrm{C}$; water temperature: $23-30.5^{\circ} \mathrm{C}$; salinity: $26.1-35.6 \mathrm{ppt}$; pH: 7.4 - 8.3; turbidity: $0.17-1.19$ NTU; ammonia-N: 0.03 - $0.034 \mathrm{mg} \mathrm{l}^{-1}$; nitrite-N: $0.007-0.048 \mathrm{mg} \mathrm{l}^{-1}$; nitrate-N: $0.056-0.337 \mathrm{mg} \mathrm{l}^{-1}$; phosphate: $0.057-0.179$ $\mathrm{mg} \mathrm{l}^{-1}$; silicate: $0.15-0.84 \mathrm{mg} \mathrm{l}^{-1}$; dissolved oxygen: 3.77 - $5.41 \mathrm{mg} \mathrm{l}^{-1}$; net primary productivity: $35-270 \mathrm{mg} \mathrm{cm}^{-3}$ day $^{-1}$; gross primary productivity : $116-470 \mathrm{mg} \mathrm{cm}^{-3}$ day $^{-1}$ and chlorophyll a: $1.892-2.954 \mathrm{mg} \mathrm{m}^{-3}$.

\section{Discussion}

The present study conducted, pertains to the growth of strip spawned, hatchery produced $P$. imbricata fucata spat under different rearing conditions. Results of the study give some clues for optimising the stocking density for better growth and survival.

In the first experiment conducted, maximum growth and survival was observed in micron meshed cages than those reared in FRP tanks. Results indicated that micron meshed cage was found to be a better alternative for nursery rearing phase of $P$. imbricata fucata spat. During the second experiment, juveniles reared at stocking densities up to 400 nos. per basket neither showed any particular variation in their growth rates and survival in the fifth month. Due to increased fouling all through the months of June - July, compared to first and third month. Results of the third experiment conducted on growth of subadults in box cages at different stocking densities showed that reducing the oyster density to 500/600 nos. per box cage during the third month will enhance rapid and healthy growth.

Transfer of juveniles from plastic baskets to box cages after five months of rearing rapidly enhanced growth rates which indicated the significance of spatial requirement for enhancement of growth rate. Monteforte et al. (2005), studied the effect of stocking density on growth and survival of the rainbow pearl oyster, Pteria sterna and reported density reduction as a useful protocol during the nursery culture phase. In contrast, Aji (2011) reported on the high withstanding capacity of juveniles of P. sterna to high stocking density. Taylor et al. (1997) also studied on the effects of stocking density on the growth and survival rate of early juvenile silver-lip pearl oyster, $P$. maxima in suspended nursery culture phase and reported that maximum growth and survival rate was observed at a density of 1.3 juveniles per $100 \mathrm{~cm}^{3}$.

Increase in stocking density retards growth rate by preventing free flow of water and thereby food availability. Ky et al. (2015) reported that stocking density affects growth of $P$. margaretifera, reducing the availability of food and oxygen which alters the physiological processes. Frechette et al. (1996), also reported on self thinning of oysters at high population density.

Results of the present growth trials conducted on subadults stocked in box cages showed 98.5-98.6\% survival rates at stocking densities of 200, 300 and 400 nos. per cage during the fifth month. Although no particular difference was noted in the DVM, HL and THK of oysters stocked at densities of 300 and 400, an inverse relationship was observed between higher stocking densities and average weight of the oysters. Appukuttan (1987) recorded a growth rate of $1.5 \mathrm{~mm}$ per month for $45-49 \mathrm{~mm}$ sized P. fucata in Vizhinjam Bay stocked at a density of 100 nos. per cage and reported on rapid growth rate for younger stages. Rao (2007) recorded a mean DVM of $56.17 \mathrm{~mm}$ and $72.11 \mathrm{~mm}$ in $1^{\text {st }}$ and $2^{\text {nd }}$ year with a maximum growth of 65 and $85 \mathrm{~mm}$ in P. fucata. Devanesan and Chidambaram (1956), reported an increase in height up to $36 \mathrm{~mm}$ in 6 months, $35-45 \mathrm{~mm}$ at the end of one year, $50-55 \mathrm{~mm}$ at the end of the second year, 55-60 $\mathrm{mm}$ at the end of the third year, $60-65 \mathrm{~mm}$ at the end of the fourth year and $65-70 \mathrm{~mm}$ at the end of the fifth year in P. fucata. Victor et al. (2000) reported a growth rate of $6.3 \mathrm{~mm}$ per month for $7.2 \mathrm{~mm}$ sized P. fucata spats stocked at a density of 1500 nos. per cage. 
Results of the present study revealed that micron meshed cage is a feasible alternative for the rearing of oyster spats during its initial phase of nursery rearing in open sea. During their further open sea rearing in plastic baskets and box cages, higher stocking densities resulted in stunted growth and mortality of oysters. Results indicated that stocking density of 400 nos. per cage favours better optimisation of resource for juveniles of size $38-39 \mathrm{~mm}$ to the subadults of size up to $50-51 \mathrm{~mm}$. For adults ranging from $52-56 \mathrm{~mm}$, a stocking density of 400 nos. per cage seems better for a period of four months. When the oysters reach 58-60 mm (DVM), a reduction in stocking density to 100 nos. per cage resulted in better growth and survival thereafter. Reduction in stocking density enhances rapid flow of seawater inside the cage and better feed availability which aids in proper growth and maximum survival percentage.

\section{Acknowledgements}

The authors are grateful to the Director, ICARCMFRI, Kochi and Management of Fatima Mata National College (Autonomous), Kollam for providing facilities for the work. Authors also express sincere gratitude to Government of Kerala for e-grants provided.

\section{Reference}

Aji, L. P. 2011. An overview of the method, management, problem and their solution in the pearl oyster (Pinctada margaritifera) culture. J. Coast. Dev., 14(3): 181-190.

Anil, M. K., Mary Rinju, R., Sugi, V. V., Raju, B. and Benziger, V. P. 2014. Seed production of Indian pearl oyster Pinctada fucata for image pearl production. In: Anil, M. K. (Ed.), Course manual, Marine image pearl production. ICAR-Central Marine Fisheries Research Institute, Vizhinjam, Kerala, India. p. 19-33.

Appukuttan, K. K. 1987. Pearl oyster culture in Vizhinjam Bay. In: Pearl culture, CMFRI Bulletin, 39: 54-61.

Devanesan, D. W. and Chidambaram, K. 1956. Results obtained at the pearl culture farm, Krusadai Island, Gulf of Mannar and their application to problems relating to pearl fisheries in the Gulf of Mannar - I. Contribution from the Marine Fishery Biological Station, Krusadai Island, Gulf of Mannar, Tamil Nadu, India, 4: 89 pp.

Frechette, M., Bergeron, P. and Gagnon, P. 1996. On the use of self-thinning relationships in stocking experiments. Aquaculture, 145: 91-112. DOI: 10.1016/S0044-8486(96) 01349-X.

Jagadis, I., Ignatius, B., Victor, A. C. C. and Ilangovan, K. 2006. Production of mother oysters of Pinctada fucata (Gould) by manipulation of stocking density. Indian J. Fish., 53(3): 297-305.

Ky, C. L., Lau, C., Koua, M. S. and Lo, C. 2015. Growth performance comparison of Pinctada margaritifera juveniles produced by thermal shock or gonad scarification spawning procedures. J. Shellfish Res., 34(3): 811 - 817.

Liu, W., Huang, X., Lin, J. and He, M. 2012. Seawater acidification and elevated temperature affect gene expression patterns of the pearl oyster Pinctada fucata. PlosOne, 7(3).

Monteforte, M., Bervera, H., Juan, J. R., Saucedo, P. and Cesar, O. L. 2005. Effect of stocking density on growth and survival of the rainbow pearl oyster Pteria sterna (Gould 1852) during nursery and late culture in Bahia de La Paz, Baja California Sur, Mexico. Aquac. Int., 13: 391-407.

Matthew, W. and Paul, C. S. 2016. The effects of stocking density and ration on survival and growth of winged pearl oyster (Pteria penguin) larvae fed commercially available micro-algae concentrates. Aquac. Reports, 4: 17-21. DOI: 10.1016/j.aqrep.2016.05.004.

Rao, K. V. and Rao, K. S. 1974. The commercial molluscs of India, In: CMFRI Bulletin, 25. ICAR-Central Marine Fisheries Research Institute, Kochi, India, p. 84-105.

Rao, G. S. 2007. Growth and biometric relationship of the Indian pearl oyster Pinctada fucata (Gould) under long term onshore rearing system. J. Mar. Biol. Ass. India, 49(1): 51-57.

Sims, N. A. 1994. Growth of wild and cultured black-lip pearl oyster, Pinctada margaritifera (L.) (Pteriidae; Bivalvia), in the Coll Islands. Aquaculture, 122: 181-191.

Southgate, P. C. and Beer, A. C. 2000. Growth of blacklip pearl oyster Pinctada margaritifera juveniles using different nursery culture techniques. Aquaculture, 187: 97-104.

Strickland, J. D. H. and Parsons, T. R. 1972. A practical handbook of seawater analysis. Bull. Fish. Res. Board Canada, 167: $310 \mathrm{pp}$.

Taylor, J. J., Rose, R. A., Southgate, P. C. and Taylor, C. E. 1997. Effects of stocking density on growth and survival of early juvenile silver-lip pearl oysters, Pinctada maxima (Jameson), held in suspended nursery culture. Aquaculture, 153: 41-49. DOI: 10.1016/s0044-8486(97)00015-x.

Victor, A. C. C., Kandasami, D., Jagadis, I., Boby, I., Chellam, A. G., Chitra, P. V. and Rajkumar,M. 2000. Results of the mother oyster culture and pearl production in Pinctada fucata (Gould) in the inshore waters of the Gulf of Mannar and Palk Bay. In: Perspectives in Mariculture, The Marine Biological Association of India, Kochi, Kerala, India. p. 251-258.

Winkler, L. W. 1888. Determination of dissolved oxygen in the water. Ber. Dtsch. Chem. Ges., 21: 2843 - 2853 (In German). 